\begin{abstract}
ARTICLES
\section{DELEVERAGING MICROFINANCE: PRINCIPLES FOR MANAGING VOLUNTARY DEBT WORKOUTS OF MICROFINANCE INSTITUTIONS}

\author{
Deborah Burand
}

"No one ever ended poverty by going bankrupt."

John Hatch, founder of FINCA International ${ }^{1}$

Approximately 2.6 billion people, roughly 40 percent of the world's population, live on less than $\$ 2^{2}$ a day. ${ }^{3}$ Of these people, 1.4 billion-that is one in four people in the developing world-live in extreme poverty subsisting on less than $\$ 1.25$ a day. ${ }^{4}$ According to recent World Bank estimates, the financial and economic crisis facing the world today is likely to trap another 53 million people in extreme poverty. ${ }^{5}$

* Clinical Assistant Professor, and Director, International Transactions Clinic, University of Michigan Law School.

1. Sam Daley-Harris, State of the Microcredit Summit Campaign Report 2009, at 14 (2009) (quoting John Hatch), available at http://www.microcreditsummit.org/state_of_the_campaign_report/ [hereinafter Microcredit Summit Campaign Report 2009].

2. All monetary figures are in U.S. dollars.

3. Press Release, The World Bank, New Data Shows 1.4 Billion Live on Less Than US\$1.25 A Day, But Progress Against Poverty Remains Strong (Aug. 26, 2008), available at http://web.worldbank.org/ WBSITE/EXTERNAL/NEWS/0, pagePK:34382 piPK:34439 theSitePK:4607,00.html (follow "press releases" hyperlink and search by date).

4. Id.

5. Robert B. Zoellick, President, The World Bank Group, Address at Thompson Reuters Building, Canary Wharf, London, Seizing Opportunity from Crisis: Making Multilateralism Work (Mar. 31, 2009), available at http://web.worldbank.org/WBSITE/EXTERNAL/NEWS/0,,pagePK:34382 piPK:34439 the SitePK:4607,00.html (follow “speeches” hyperlink and search by date) [hereinafter Zoellick Speech]. 
Most of this poor population lack access to credit and other important financial services. The aggregate amount of microcredit in the world is over $\$ 30$ billion, reaching over 150 million people. ${ }^{6}$ While that is a large amount, particularly when one considers that much of this $\$ 30$ billion is being lent to microentrepreneurs in loan denominations as small as $\$ 30$ or $\$ 50$, the current supply of microcredit is but a small fraction of the outstanding demand. Some have estimated that the overall demand for microcredit is approximately $\$ 275$ billion, reaching a customer base of one billion people living on less than $\$ 2$ a day. ${ }^{7}$

To meet that demand, the microfinance sector needs to attract much more capital. Yet, at the end of 2007, many stakeholders in the microfinance sector were worrying about the large amounts and fast pace of capital flowing into microfinance providers, much of which was being invested in the form of debt financing. ${ }^{8}$

Today, one year later, capital flows into the microfinance sector are slowing. ${ }^{9}$ As a result, microfinance providers that once were flush with cash

6. Centre for the Study of Financial Innovation, Microfinance Banana Skins 2009: Confronting crisis and change, 2009 Centre for the Study of Fin. Innovation 5 [hereinafter 2009 Banana Skins Report] (the 1200 microfinance institutions reporting to the Microfinance Information eXchange (MIX) have in total $\$ 32$ billion in assets); see also Microcredit Summit Campaign Report 2009, supra note 1, at 3 (as of December 31, 2007, 3,552 microcredit institutions report having reached in the aggregate 154,825,825 clients with microcredit); see also CGAP, Microfinance Donors \& Investors, available at http://www.cgap .org/p/site/c/template.rc/1.11.1792/1.26.2114/; see generally Raimer Diekmann, Deutsche Bank Research, Microfinance: An Emerging Investment Opportunity, 7 (Dec. 19, 2007), available at "http://www .dbresearch.com/PROD/DBR_INTERNET_EN-PROD/PROD0000000000219174.pdf [hereinafter Deutsche Bank Research] (noting that the volume of microcredit grew by over 20 billion in five years from an estimated 4 billion in 2001 to approximately 25 billion in 2006).

7. Deutsche Bank Research, supra note 6, at 10.

8. CGAP, Who is Funding Microfinance: Results of the First Global Survey of Funders' Microfinance Portfolio (Nov. 2008), available at http://www.cgap.org/gm/document-1.9.7448/2008\%20 Funder\%20Survey-resource\%20presentation\%20final.pdf [hereinafter CGAP 2008 Funding Survey]. In a CGAP-sponsored survey of 54 respondents (33 donors and 21 investors) making cross-border investments in microfinance providers, $63 \%$ was invested in the form of debt. Id. See also Sebastian von Stauffenberg, Cautious Resilience: The Impact of the Global Financial Crisis on Latin American \& Caribbean Microfinance Institutions, MicroRate, Inc. 32 (Mar. 2009), available at $\mathrm{http} / / / \mathrm{microrate} . c o m / w p-c o n t e n t /$ uploads/2009/03/cautious-resilience2.pdf [hereinafter Cautious Resilience]. Debt investments account for approximately $91 \%$ of the surveyed microfinance investment vehicles' investments in Latin American microfinance providers. Id.

9. Elizabeth Littlefield \& Christoph Kneiding, The Global Financial Crisis and Its Impact on Microfinance, 52 CGAP Focus Note 3 (Feb. 2009), available at http://www.cgap.org/gm/document1.1.1305/FN_52\%20ENG.pdf; see also CGAP, CGAP's Virtual Conference Highlights: How Will Microfinance Weather the Financial Crisis Storm?, available at http://www.cgap.org/p/site/c/template.rc/ 1.26.4301/. CGAP sponsored a virtual conference in November 2008 to examine how the current global financial crisis is impacting microfinance. Id. Participants in that conference noted that some microfinance 
are now facing or likely to face significant refinancing risk. If this risk is not managed properly, we may see liquidity and even insolvency challenges plaguing the microfinance sector.

This paper focuses on the challenges of responding to a deleveraging of the microfinance sector and offers guidelines for stakeholders in microfinance - regulators, policymakers, investors (debt and equity), donors, and microfinance providers - for how to address these challenges in the context of a microfinance institution debt workout so as to minimize undue disruption and damage to the microfinance sector as a whole.

\section{What We Thought in December 2007-Too Much Too Fast}

The financing of microfinance has been a quickly changing picture in recent years as microfinance institutions increasingly have tapped commercial sources of funding and become less reliant on donor grants or subsidized funding to finance their microcredit portfolios. International (as opposed to domestic) investors also have become a significant source of this new funding flowing into the microfinance sector. ${ }^{10}$ This shift from grant funding to more commercial forms of capital provided by international funders is even more evident when one looks at the proliferation of specialized microfinance investment vehicles ("MIVs"). ${ }^{11}$ Investments by MIVs in microfinance grew by $639 \%$ from 2004 to $2007 .{ }^{12}$ As of December 31, 2007, 91 MIVs had, in

providers were seeing capital sources shifting and, in some countries and regions, capital flows were slowing or stopping. Id. One interesting exception to this downturn in microfinance funding is the growth experienced by online lending platforms that are focused on microfinance, like Kiva and Microplace. In the last quarter of 2008, funding amounts of these two platforms increased-in absolute amounts and in number of investors. See generally Deborah Burand, Microfinance Managers Consider Online Funding: Is it Finance, Marketing, or Something Else Entirely?, 54 CGAP Focus Note (Apr. 2009); see also Press Release, Kiva.org, Lending Through Kiva.org Repaid at 98 Percent; Despite Economic Downturn, Kiva Lenders Continue to Invest for Social Return (Nov. 11, 2008), available at http://www.kiva.org/about/ release_20081111. In October 2008, Kiva lenders loaned a record \$3.6 million, its highest loan volume for any single month since Kiva's launch. Id.

10. CGAP 2008 Funding Survey, supra note 8. While based on self-reported data (mostly as of December 2007) from 54 respondents (33 donors and 21 investors), CGAP found that its surveyed respondents have committed nearly $\$ 11.7$ billion to funding microfinance. Id. Of this $\$ 11.7$ billion, only $19 \%$ is in the form of grants. Id.

11. MicroRate defines MIVs as independent investment vehicles that must: 1) be an independent legal entity; 2) open to or including multiple investors; and 3) focusing on investing in microfinance. Cautious Resilience, supra note 8, at 29.

12. Cautious Resilience, supra note 8, at 30 (describing findings of a 2008 MicroRate Survey). See also Xavier Reille \& Sarah Forster, Foreign Capital Investment in Microfinance: Balancing Social and Financial Returns, 44 CGAP Focus Note 1 (Feb. 2008). 
aggregate, $\$ 5.4$ billion under management. ${ }^{13}$ By December 31, 2008, there were 103 active MIVs with, in aggregate, $\$ 6.6$ billion in their portfolios. ${ }^{14}$

The amount and pace of financing pouring into microfinance in recent years led a number of observers to suggest as recently as late 2007 that the availability of capital was not a major problem for microfinance and that, rather, the problem confronting microfinance could be one of too much funding, although a few warned of a possible refinancing risk should microfinance fall "out of fashion." 15 A commonly held view was that "the flood of international capital, coupled with new domestic sources in many markets, means capital availability isn't the problem. In fact over abundance presents a much bigger risk." 16

A March 2008 study of the primary risk factors in the microfinance industry highlighted the prevalent view that the microfinance sector was awash in funding and that the sheer amount and pace of funding flowing into microfinance providers could pose a risk to the sector. This "2008 Microfinance Banana Skins Report" assessed risk in the microfinance sector as perceived by 305 respondents from 74 countries and multinational institutions. Risks were divided into two categories - the "biggest risks" and the "fastest risers"; and then, within these two categories, risks were ranked from 1 to 29 ( 1 being the biggest or fastest rising risks). The top five "biggest risks" identified in the 2008 Banana Skins Report were: 1) management quality; 2) corporate governance; 3) inappropriate regulation; 4) cost control; and 5) staffing. Ranked number four among the top five "fastest risers" of risks was "too much funding." At the very bottom of both lists, ranked as number 29 , was the risk of "too little funding."

13. Shawn Marie Murphy, Impact of Global Financial Crisis on Microfinance, 6 Found. For DEv. Corp. 2, at 1 (2008), available at http://www.fdc.org.au/files/Publications/FDC-Briefing-Note-Nov-08.pdf.

14. Microfinance Funds: Still growing-with increased focus on social responsibility (www.CGAP.org, Sept. 17, 2009) (MIVs grew at 31 percent on average in 2008 compared to 72 percent in 2007).

15. Centre for the Study of Financial Innovation, Microfinance Banana Skins 2008: Risk in a Booming Industry, 2008 CENTRE FOR THE STUDY OF Fin. INNOVATION 8, available at http://www.cgap.org/ gm/document-1.9.2956/MF_BananaSkins2008.pdf [hereinafter 2008 Microfinance Banana Skins Report].

16. Id. at 32 (quoting Timothy Lyman, advisor to CGAP).

17. Id. at $6 ; c f . i d$. at 33 (noting, however, that there continued to be "funding-starved" microfinance providers that were not enjoying the abundant funding flowing into the microfinance sector. These poorly funded microfinance providers tended to be small, unprofitable, unregulated or located in remote areas, or adhered to a social mission that made it unlikely that the microfinance provider ever would become commercial). 


\section{What We Think Now in 2009: Too Little and Too Expensive}

Since the global financial crisis, however, capital availability is becoming an issue of concern as the amount of funding for microfinance declines and the terms of available funding tighten. A new Banana Skins Report, which compiled 430 survey respondents from 82 countries and multinational institutions, paints a very different picture of the perceived risks facing microfinance in 2009. The top six risks, in rank order of highest perceived risk, in the 2009 Banana Skins Report were: 1) credit risk (up from number 10 in the 2008 Banana Skins Report), 2) liquidity (up from number 20 in the 2008 Banana Skins Report), 3) macro-economic trends (up from number 23 in the 2008 Banana Skins Report), 4) management quality (down from number 1 in the 2008 Banana Skins Report), 5) refinancing (up from 28 in the 2008 Banana Skins Report), and 6) too little funding (up from 29 in the 2008 Banana Skins Report). At the very bottom of the 2009 Banana Skins report is the perceived risk of "too much funding" (dropping down from 4 in the 2008 Banana Skins Report). ${ }^{18}$

While there are regional differences in these perceived risks, a report issued in March 2009 by MicroRate, a specialized rating agency for microfinance, commented,

[i]n the current financial environment, "too little funding" would probably top the industry's biggest risks list. The slowdown in [microcredit] portfolio growth is most notably due to the increased uncertainty of sources of funding. As economies slow down and credit markets tighten, both domestic, and even more so, international capital becomes scarce. ${ }^{19}$

The Microrate report then lists challenges that Latin American microfinance institutions now cite as their five biggest risks. These are: 1) decreases in their liquidity; 2) deterioration of the quality of their microcredit portfolios; 3 ) increasing credit risk profiles of microentrepreneur clients; 4) increasing costs of funding; ${ }^{20}$ and 5) possibility of government interference in microfinance. ${ }^{21}$

18. See 2009 Banana Skins Report, supra note 6, at 6.

19. Cautious Resilience, supra note 8, at 9.

20. CGAP recently reported steep increases in the rates currently being charged to microfinance providers "from 250 basis points (bps) in Eastern Europe, to as high as 400 bps in some Latin American countries, to 450 bps or more for top-tier institutions in South Asia." Littlefield \& Kneiding, supra note 9, at 3 .

According to recent interviews conducted by MicroRate with MIVs investing in Latin America, there is an observable tightening of the amount and terms of credit available to Latin American microfinance institutions. Cautious Resilience, supra note 8, at 33. Interest rates are increasing while tenors are 
At issue is the question of how vulnerable microfinance is to more general declines in private capital flows to emerging markets. ${ }^{22}$ In an environment where net flows of private capital to emerging markets are expected to drop sharply in 2009 from that of $2008,{ }^{23}$ will microfinance also feel the pinch?

Many in the microfinance sector believe it will as they look at the refinancing risks likely to face microfinance providers when outstanding debt obligations loans come due in 2009 and in $2010 .{ }^{24}$ Due to the relatively short tenors of debt funding in the microfinance sector combined with a large amount of cross-border financing that is denominated in hard, not local, currency, ${ }^{25}$ this refinancing risk is not a trivial amount. According to CGAP, five large funders of microfinance estimate that in 2009 the microfinance providers within their respective portfolios will need to refinance, in aggregate, approximately $\$ 1.8$ billion. ${ }^{26}$

decreasing. Id. The interviewed MIVs observed that interest rates charged to microfinance institutions recently have been increasing from 50 to 200 basis points, and, in a few instances, have exceeded 400 basis points. Id. Similarly, the tenors of these loans, which in the past were averaging four to five years, now are shortening to one to three years. $I d$.

21. Id. at 12 .

22. According to the World Bank, net inflows of private capital to the developing world is expected to drop to about one-third of the peak $\$ 1.2$ trillion reached in 2007. Zoellick Speech, supra note 5. Remittances also are on a decline, with a fall of at least $5 \%$ forecast for 2009. Id. World Bank estimates that 84 out of 109 developing countries will face a financing shortfall in 2009 of $\$ 270$ to $\$ 700$ billion. Id.

23. See Capital Flows to Emerging Market Economies, Inst. Of InT'L Fin. 1 (Oct. 12, 2008) (current forecast for net flows of private capital to emerging markets in 2009 is expected to total U.S. \$562 billion, a drop of U.S. $\$ 60$ billion from 2008).

24. Littlefield \& Kneiding, supra note 9 , at 3.

25. CGAP estimates that $70 \%$ of microfinance providers' cross-border borrowing is denominated in hard currency even though the bulk of their assets (e.g., microcredit portfolios) are typically denominated in local currency. See Reille \& Forster, supra note 12.

In a January 2009 analysis of the microfinance sector by the rating agency, Fitch Ratings, Fitch concluded that adverse currency movements and mismatched assets and liabilities are likely to cause significant problems for some microfinance institutions. See Microfinance-Testing Its Resilience to the Global Financial Crisis, Fitch Ratings Financial Services Special Report 2 (Jan. 22, 2009), available at http://www.fitchratings.com/ (search "Microfinance-Testing Its Resilience to the Global Financial Crisis" and create free username and password to access the Fitch Ratings report).

26. Littlefield \& Kneiding, supra note 9 , at 3 . These funders include three large microfinance fund managers, IFC (International Finance Corporation, the private sector lending arm of the World Bank Group), and the KfW (originally called Kreditanstalt fur Wiederaufbau-hence KfW, a German development-oriented bank that is owned by the Federal Republic of Germany and the Lander (federal states)). Id. at 3-4. 


\section{The Perfect Storm: When “Doing Good” Does Not Do So Well}

It has all the makings of a perfect storm, where one unfortunate event spills over and contributes to a gradual worsening of already bad conditions. Imagine this nightmare scenario for a hypothetical microfinance institution, called here "Doing Good."

As access to credit contracts globally, international investors in microfinance slow their funding to Doing Good. In some cases, these investors try to withdraw their existing investments or, at the very least, decline to extend new or renew current credit lines to Doing Good. Facing funding challenges of their own, domestic lenders also stop lending to Doing Good.

With loan capital becoming scarce, Doing Good slows the growth of its microcredit portfolio. Unfortunately, however, when its clients recognize that there is little chance of receiving additional extensions of microcredit from Doing Good, their willingness to repay existing microcredits to Doing Good dwindles. As a result of rising microcredit delinquencies and defaults, the asset quality of Doing Good's microcredit portfolio begins to deteriorate. ${ }^{27}$ Eventually, with arrears in its microcredit portfolio increasing, Doing Good's earnings drop.

Unfortunately, this could not happen at a worse time for Doing Good. As its existing lines of credit and finance come due, traditional sources of repayment - such as earnings from its microcredit portfolio and new borrowings from lenders to the microfinance sector-are drying up, thereby increasing Doing Good's refinancing risk and liquidity risk. Moreover, much of the debt previously provided by international lenders to Doing Good that is now coming due is denominated in dollars and euros, not the local currency of Doing Good's operations (namely, its microcredit portfolio). As a result of the financial crisis, this local currency has been depreciating steeply in value against the dollar and euro. ${ }^{28}$ Unfortunately, all of Doing Good's foreign

27. According to CGAP research, this correlation between slowing growth and deteriorating microcredit portfolio quality already is happening for at least one microfinance institution in Rwanda. Id. at 4 . This Rwandan microfinance institution recently slowed its microcredit growth only to experience an increase in microcredit defaults. $I d$. Its clients, recognizing that there was little chance of receiving more microcredit, no longer saw a reason to repay their current microcredits. Id.

28. Again, this is not a purely hypothetical story. CGAP notes that microfinance institutions that have borrowed in foreign currency now are experiencing interest rate increases and currency depreciation as local currency exchange rates have been dropping against the dollar in recent months. Even before the current crisis, foreign exchange losses have accounted for losses ranging from seven to $43 \%$ of some microfinance institutions' profits in recent years. In one of the most extreme cases, a Latin American microfinance provider is reported to have suffered a loss of $75 \%$ in a single year due to foreign exchange 
currency denominated debt is unhedged, so this depreciation puts further pressure on Doing Good's capacity to repay its foreign currency debt obligations as they come due. ${ }^{29}$

If not managed properly, these refinancing, liquidity, and foreign exchange risks could endanger Doing Good's solvency. As stakeholders of Doing Good watch with growing concern, Doing Good fails to make a principal payment on one of its foreign currency denominated loans. This payment default, in turn, triggers the cross-default provisions found in several of Doing Good's other loan agreements. ${ }^{30}$ As a result, Doing Good's creditors initiate a creditor-led intervention. Doing Good soon is thrust into a nightmarish sea on which it is ill-prepared to navigate - a sea of debt workouts, restructurings and reschedulings.

Neighboring microfinance providers may watch this scene unfold with a bit of relief that they are not similarly situated. Unbeknownst to them, however, this storm does not have to hit shore many times before the creditworthiness of the entire microfinance sector is called into question. Lenders to and investors in microfinance become disenchanted with the sector as a whole as they watch once fast-growing microfinance institutions ${ }^{31}$ struggle to maintain high quality microcredit portfolios while meeting their own debt obligations. Some microfinance creditors and investors decide to limit their losses by cutting credit lines and disinvesting from most of their microfinance investments. Soon Doing Good is just one of many microfinance institutions that are beset by debt financings gone awry.

losses. See Littlefield \& Kneiding, supra note 9, at 4.

29. Doing Good, while a hypothetical microfinance provider, reflects many in the microfinance sector that have borrowed in foreign currency and then taken little to no steps to mitigate the risk of an adverse foreign exchange rate movement. A CGAP survey conducted in 2005 indicated that only $25 \%$ of microfinance institutions with foreign currency denominated borrowings are hedging against depreciation or devaluation risk, and $25 \%$ are only partially hedging. See Featherstone, Littlefield \& Mwangi, Foreign Exchange Rate Risk in Microfinance: What Is It and How Can It Be Managed?, CGAP Focus Note No. 31, 3 (Jan. 2006), available at www.cgap.org.

30. It is not unusual for loans to microfinance institutions to contain cross-default provisions. See Section 6.1(h) of Form of Credit Agreement used by Microcredit Enterprises (Jan. 2009), available at www.mcenterprises.org. Friendlier to a microfinance borrower would be a cross-acceleration clause that triggers an Event of Default only if a lender under another loan agreement actually exercises its right to accelerate the borrower's debt obligation.

31. A microfinance providers' annual growth is often in the double digits. MicroRate notes that the annual growth rate of microfinance providers that it tracks in Latin America and the Caribbean has been over $40 \%$ a year since 2002. Cautious Resilience, supra note 8, at 7 . MicroRate also predicts that "after many years of uninterrupted growth, few MFIs [microfinance institutions] are accustomed to operating under adverse environments which leaves a real possibility that some MFIs may fail." Id. at 1. 


\section{Strategies for Weathering the Storm}

If the 2008 and 2009 Microfinance Banana Skins Reports were right about the risks that are prevalent in the microfinance sector, then how well will the microfinance sector navigate this brewing storm? The likely answer is not well, unless stakeholders in the microfinance sector start to articulate and develop strategies for managing a deleveraging of the microfinance sector. Now is the time to take steps to ensure that any departing capital flows exit the microfinance sector gracefully without undue disruption to the sector as a whole. $^{32}$

A borrower in financial distress generally has two options. It can seek a resolution of its problems in an informal, consensual, non-judicial way or it can seek judicial protection under applicable bankruptcy laws. ${ }^{33}$ For some microfinance institutions, there may be well-articulated bankruptcy laws and regulations that can provide an overly indebted microfinance institution with some form of relief. For other microfinance institutions, however, due to their legal form (or lack thereof) it is questionable whether such relief would be applicable. Moreover, in many cases, even if bankruptcy protection is available to a microfinance institution, the microfinance institution may be better off attempting to negotiate a more informal, out-of-court, debt rescheduling or restructuring with its creditors before resorting to such protection.

Yet even a more informal debt workout process is likely to pose challenges to a troubled microfinance institution. For starters, there is likely to be a steep learning curve for any microfinance institution sitting down with

32. There are, of course, actions that microfinance providers can and should take to try to prevent the worst-case scenario presented here and a resulting debt workout. CGAP recently suggested several sensible steps for microfinance stakeholders to consider. For the microfinance manager, these include steps to: 1) increase reserves; 2) adjust growth plans to be more conservative; 3) grant prompt follow-on microcredits to existing clients who have repaid faithfully in order to avoid destroying their repayment motivations; 4) focus on sound lending practices, including appraising clients' repayment ability; 5) communicate proactively and openly with lenders and investors about refinancing concerns and other issues that could impact the microfinance provider's financial performance and capacity to meet its debt obligations; 6) pay greater attention to asset-liability management especially maturity mismatches and foreign currency exposure; 7) rationalize or diversify funding sources to a manageable but balanced number; and 8) take steps to become licensed to mobilize deposits from the public so as to limit the microfinance provider's dependence on cross-border funding. See Littlefield \& Kneiding, supra note 9, at 6.

33. Esteban C. Buljevich, Cross Border Debt Restructurings: Innovative Approaches FOR CREDITORs, CORPORATES AND SOVEREIGNS, Ch. 2 "Out-of-court debt restructurings a.k.a. workouts," 28 (2005). 
a group of its creditors. This may be the first time that the microfinance institution has held an intercreditor negotiation of any type since much of the debt outstanding in the microfinance sector to date has been lent in the form of "single bank" loans, not "syndicated" loans. ${ }^{34}$ For a microfinance institution that is inexperienced in negotiating with groups of creditors, securing skilled legal and financial advisors will be a crucial first step to reaching a successful resolution of its problems. ${ }^{35}$

When a troubled microfinance institution does begin discussions with its creditors, high on the agenda will be at least four basic questions - namely, how much can be paid, how much must be deferred (and by whom), when are such payments or deferrals to be made, and at what price? ${ }^{36}$ In some negotiations, there may yet another question put on the agenda - will existing creditors be willing to extend any additional "new" financing to the microfinance institution to help it through this difficult period? ${ }^{37}$

Time is important in any financial workout. In the workout of a distressed microfinance institution, reaching agreement quickly may be crucial to the ultimate success of the negotiations and survival of the microfinance institution. Delays not only can prolong uncertainty and increase the costs to the borrower and its creditors, but delays also can contribute to an erosion of much of the distressed microfinance institution's economic value if the asset quality of the microcredit portfolio is allowed to deteriorate either due to contractions in its microlending activity or distraction of the microfinance

34. There are, of course, exceptions to this general statement. For example, Kashf, a microfinance institution operating in Pakistan, in late May of 2007 signed a U.S. \$8 million loan facility with a syndicate of Pakistani commercial banks, the first local currency syndication to take place in Pakistan for a microfinance institution. See Press Release, Grameen Foundation, Grameen Foundation Supports Landmark deal for Kashf Foundation in Pakistan: First local currency syndication transaction for Pakistani Microfinance Sector (May 31, 2007), available at http://www.csrwire.com/press/press_release/20275Grameen-Foundation-Supports-Landmark-deal-for-Kashf-Foundation-in-Pakistan.

35. Even more experienced microfinance institutions would be well-advised to secure legal and financial advisors to help steer these negotiations. Hiring both local and international legal counsel is likely to be necessary if any of the debt to be rescheduled or restructured is governed by the law of a country other than that of the microfinance institution.

36. These questions will sound familiar to any one with experience in debt workouts - even those working more than two decades ago on a sovereign debt restructuring. See, e.g., Alfred Mudge, Sovereign Debt Restructure: A Perspective of Counsel to Agent Banks, Bank Advisory Groups and Servicing Banks, 23 Colum. J. Transnat'L L. 59 (1984).

37. This is to simplify greatly as debt workouts can take many forms. Parties, for example, can agree to reschedule existing debt obligations (by extending the debt obligations' principal maturities, lowering interest rates, deferring interest payments, or even capitalizing interest payments, to name a few). Or, parties can agree to restructure these debt obligations (by buying back the debt obligation for cash, exchanging the debt obligation for a new debt obligation (debt-for-debt exchange), exchanging the debt obligation for equity (debt-for-equity exchange), or some combination thereof). 
institution's management away from conducting day-to-day operations. Creditors also may have limited tolerance for a lengthy and costly negotiating process, particularly if the amounts at stake are relatively small. In sum, the implementation of the plan (and the process of negotiation to reach agreement to such a plan) needs to avoid damaging the business operations of the borrowing microfinance institution so that its going concern value is not impaired. This requires a speedy negotiation and implementation of the plan and, in some circumstances, even may require a standstill period during which all affected creditors agree to forego taking any enforcement actions against the borrower so long as negotiations proceed in good faith. ${ }^{38}$

Unlike many corporate and sovereign debt workouts, the amounts involved in a microfinance institution's debt workout often will be relatively small in size. Yet these negotiations still are likely to be complex, particularly where international lenders are involved. The success of these negotiations will turn on the extent to which, as in workouts, reschedulings and restructurings in other contexts, the parties agree on a plan that (i) maximizes recovery value, (ii) distributes that recovery value among creditors in a fair, transparent, and equitable manner, and (iii) imposes fair burden sharing among like classes of creditors. ${ }^{39}$

To advance a debt workout that can achieve all of the above, a distressed microfinance institution and its affected creditors may want to consider the INSOL International's Statement of Principles for a Global Approach to Multi-Creditor Workouts ("INSOL Principles"). ${ }^{40}$ While the INSOL Principles

38. See Buljevich, supra note 33, at 76 (this can be done informally or debtor and its creditors might enter into a binding contract outlining debtor-lender and lender-lender relationships during the agreed standstill period).

39. Id. at 30 . So, for example, the recovery expectations of creditors should turn on their relative status and ranking vis-à-vis other creditors: secured or senior creditors should be favored over unsecured or subordinated creditors; and unsecured or subordinated creditors should be favored over equity stakeholders.

40. Int'l Ass'n of Resctructuring, Insolvency \& Bankr. Professionals, Statement of Principles for a Global Approach to Multi-Creditor Workouts 2-3 (2000), available at http://www.insol.org/pdf/ Lenders.pdf. The INSOL Principles take a global approach to corporate debt workouts so they are intended to work with existing practices found in multiple jurisdictions. The eight INSOL Principles generally are as follows:

1. Where debtor is found in financial distress, all creditors should cooperate and allow enough time to gather appropriate information from debtor and to allow restructuring proposals to be made;

2. During this standstill period, creditors should refrain from enforcing claims against debtor so as not to prejudice others' claims; during standstill, debtor should not take any action that might adversely affect its creditors' interests;

3. Creditors should coordinate their responses by forming committees and appointing professional advisors; 
were not developed with microfinance institutions in mind, they offer an organizing structure for ensuring that best practices are adhered to by the borrower and its creditors in negotiating an expedited, consensual, out-ofcourt workout on a global basis.

Adherence to INSOL Principles (or a variation thereof) in a debt workout for a microfinance institution is likely to be complicated by some of the unique challenges confronting the microfinance sector. For example, INSOL Principles are most successful where there is an "appropriate legal, regulatory and governmental policy framework." ${ }^{.11}$ Unfortunately, that is not always, or even often, the case for many forms of microfinance providers in many parts of the world. But it is not only the lack of an appropriate and transparent legal and regulatory framework that can complicate a microfinance debt workout. Some of these unique challenges are due, at least partially, to the identities of the players that are likely to come to the negotiating table in a debt workout of a microfinance institution.

First of all, as noted earlier, senior managers of the borrower (in this case, the distressed microfinance institution) may to have little to no experience in managing this process. This can be complicated still further by Board members and equity stakeholders of the microfinance institution who also may have limited debt restructuring/workout experience and may not fully understand their respective roles in this process.

Other parties at the table might include international financial institutions, which, while likely to be the most experienced in participating in a restructuring or workout, may have limited flexibility in their respective negotiating positions for fear of setting a precedent (or upsetting an existing precedent) in how they respond to the restructuring or workout. Socially responsible investors also may be at the table - either as institutional investors or even as retail investors. These investors may be the "wild cards" of such a negotiation as their motivations, levels of patience, and willingness/capacity to contribute new funding to the microfinance institution may vary widely. It is likely, however, that no socially responsible investor would want to be

4. Debtor should provide all relevant information to its creditors;

5. All proposals and arrangements of creditors should conform to applicable law and reflect relative positions of creditors;

6. All proposals and arrangements of creditors should conform to applicable law and reflect relative positions of creditors;

7. Information concerning details of debtor's business should remain confidential; and

8. If debtor receives additional funding during standstill period or under any restructuring plan, repayment of that debt should be accorded priority status.

41. Id. at 5 . 
identified as the institution responsible for causing a microfinance institution to fold, unless there has been evidence of such significant malfeasance or other wrongdoing by the microfinance institution that the socially responsible investor fears its own good reputation could be damaged by a continued relationship with the microfinance institution.

Donors also may be involved in the negotiation of a microfinance institution's debt workout. In some cases donors may have money currently at stake in the microfinance institution - either in the form of an outstanding grant or they may have an outstanding a debt, equity or guarantee investment in the microfinance institution, albeit on a subsidized basis. Or, donors may have made grants to the microfinance institution in the past, the proceeds of which they now hope to protect. ${ }^{42}$ Like the microfinance institution's managers and Board members, donors also may be inexperienced in participating in a debt workout or restructuring. Moreover, it may be difficult politically for some government-sponsored donors to subordinate their interests to the financial interests of more commercially-oriented investors. On the other hand, donors and some of the international financial institutions may be able to provide funding in a more countercyclical fashion than commercial investors. ${ }^{43}$ Whether such funding, however, can be used to "bail out" more commercial creditors of troubled microfinance institutions remains to be seen.

Complicating things still further, there may be local government stakeholders involved in the negotiation, even if only indirectly. These government stakeholders could include local politicians or even members of the executive branch whose poor constituents are likely to be impacted adversely by a contraction or liquidation of the microfinance institution's operations. Or, if the local microfinance is regulated, the government actor could be a local regulator or supervisor. Unfortunately, the rules for liquidating and/or intervening in weak microfinance institutions are not clear

42. Some donors have asserted rights into their grant agreements that are intended to live long beyond the life of the period in which the grant funds are disbursed. Regulations governing grants by the United States Agency for International Development (“USAID”), for example, prohibit the pledging of assets that were acquired with USAID grants. In the microfinance context, this has been interpreted by some to mean that microfinance institutions should not pledge any microcredits that were originated with USAID funding. Since money is fungible, however, this can lead to some odd results as microfinance institutions try to segregate, at least by amount, those microcredits that can act as collateral for a loan and those that are ineligible to be pledged.

43. Some evidence of this is already apparent in the microfinance sector. IFC and KfW joined forces in early 2009 to create a liquidity facility of up to $\$ 500$ million for microfinance institutions. Press Release, The World Bank, "\$500 Million Microfinance Facility Backs Lenders to the Poor" (Feb. 12, 2009), available at http://web.worldbank.org/WBSITE/EXTERNAL/NEWS/0,,contentMDK:22068946 page PK:64257043 piPK:437376 theSitePK:4607,00.html. 
in many countries. And even when these rules are known, government authorities' relative lack of experience in applying these rules in the microfinance context may cause their application to be poorly implemented or vulnerable to undue political influence.

Another factor that can make these microfinance debt workouts challenging is that, although the amount of financing to the microfinance sector increased dramatically in recent years, there are relatively few institutional investors that are interested in lending to or investing in the microfinance sector. ${ }^{44}$ This limited investing community raises the risk of contagion to the sector as a whole if negotiations and related implementation processes are not managed well in any given microfinance institution's workout. On the other hand, it also could give rise to developing standard procedures for managing negotiations and the related implementation processes when the same players return to the negotiating table again and again. Whether this could lead to a more favorable resolution for the weak microfinance institution is questionable. The answer may depend on the extent to which investors negotiate with an eye on next deal and thus limit the range of concessions to which they might agree in fear of setting an unfavorable precedent for future negotiations with other microfinance institutions.

Finally, the legal standing of various creditors may not be clear in the jurisdictions where microfinance institutions operate, thereby making it difficult to allocate recovery rights and burden sharing obligations fairly and transparently among classes of creditors. This can lead to unpleasant surprises within the creditor community as creditors demand "like treatment among like creditors." Complicating this discussion still further is a troublesome and all too common practice taking place in the microfinance sector today, whereby some creditors demand "pledges" of microcredit portfolios even when pledges of pools of intangible assets are highly unusual or not perfectable. When a microfinance institution is in distress, it may be difficult for one of these socalled "secured" creditors to assert a valid priority claim over those microfinance assets that were supposed to be pledged. For microfinance institutions that are organized as not-for-profit organizations, there are likely to be questions about who will own the assets of nonprofit organization upon liquidation. In some countries, the likely answer is the government. So, creditors are likely to want to understand how they can assert claims on the

44. The proliferation of online lending platforms dedicated to microfinance suggests that the number of retail investors may be a very large pool at least in the number of investors if not in amounts invested. 
assets of the microfinance institution if the government now claims ownership of these assets.

To manage these microfinance-oriented challenges, the following are several principles for consideration that could guide future, voluntary debt workouts of microfinance institutions.

First Principle: Where possible, look to INSOL Principles to guide the structure by which the debt negotiation will be organized.

Second Principle: Adhere to a transparent process that includes all interested stakeholders.

Third Principle: Demand fair and good faith dealings by the debtor with its creditors, and among creditors.

Fourth Principle: Encourage speedy and simple solutions.

Fifth Principle: Favor "new" money over old such that creditors that provide new financing to the troubled borrower enjoy a priority over other creditors of the borrower. ${ }^{45}$

Sixth Principle: In the absence of fraud or bad faith conduct by the borrower, favor long-term, going concern, out of court resolutions.

While these six principles may seem to state the obvious, the capacity of microfinance managers and other stakeholders to abide by these principles will be severely compromised if the microfinance sector as a whole does not now embark on a training and education process. The speed with which a microfinance institution can collapse makes it clear that a "learning by doing" approach to managing debt workouts is bound to be fraught with difficulties. Anticipating and preparing for the possibility of debt crises in the microfinance sector is more important than ever if we hope to avoid broader damage to the sector. Accordingly, perhaps the most important step for successfully managing a deleveraging of the microfinance sector is to develop an education agenda for all stakeholders in the microfinance sector-one that applies to microfinance institutions, creditors, investors, guarantors, donors, and government actors. That education agenda should aim at developing consensus around principles for managing voluntary debt workouts of microfinance institutions. Setting these expectations now, and securing consensus by all significant stakeholders to such principles, should help to minimize the adverse impact that any badly managed debt workouts will have on the microfinance sector as a whole.

45. See Steven L. Schwarcz, The Easy Case for the Priority of Secured Claims in Bankruptcy, 47 DukE L.J. 425, 425-30 (1997) (availability of new money increases a debtor's liquidity, thereby reducing risk of failure and increasing expected value of unsecured claims). 